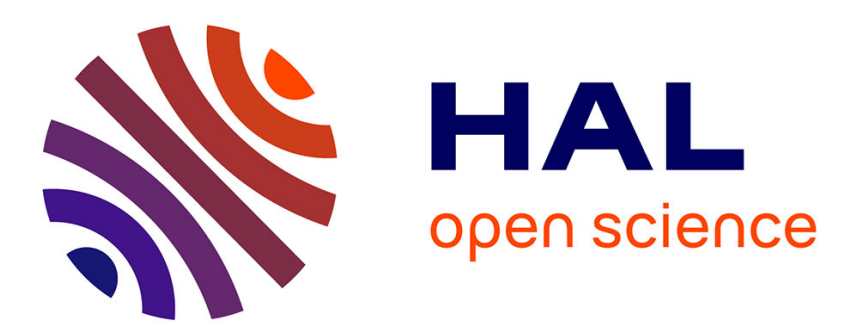

\title{
The effect of Social dominance on prejudice towards North-African minorities: Evidence for the role of social representation of Secularism as a legitimizing myth
} Jais Troian, Eric Bonetto, Florent Varet, Mathilde Barbier, Grégory Lo Monaco

\section{To cite this version:}

Jais Troian, Eric Bonetto, Florent Varet, Mathilde Barbier, Grégory Lo Monaco. The effect of Social dominance on prejudice towards North-African minorities: Evidence for the role of social representation of Secularism as a legitimizing myth. International Journal of Intercultural Relations, 2018, 65, pp96-104. hal-03234840

\author{
HAL Id: hal-03234840 \\ https://hal.science/hal-03234840
}

Submitted on 25 May 2021

HAL is a multi-disciplinary open access archive for the deposit and dissemination of scientific research documents, whether they are published or not. The documents may come from teaching and research institutions in France or abroad, or from public or private research centers.
L'archive ouverte pluridisciplinaire HAL, est destinée au dépôt et à la diffusion de documents scientifiques de niveau recherche, publiés ou non, émanant des établissements d'enseignement et de recherche français ou étrangers, des laboratoires publics ou privés. 
Accepted for publication at International Journal of Intercultural Relations (May 2018)

[For citation, please refer to authoritative final version in print]

The effect of Social Dominance on prejudice towards North-African minorities: Evidence for the role of Social Representation of Secularism as a Legitimizing Myth.

\author{
Jais Troian \\ Aix Marseille Univ, LPS, Aix-en-Provence, France
}

Eric Bonetto

Aix Marseille Univ, LPS, Aix-en-Provence, France

Florent Varet

Aix Marseille Univ, LPS, Aix-en-Provence, France

IFSTTAR-TS2-LMA, 13300, Salon-de-Provence, France

Mathilde Barbier

Aix Marseille Univ, LPS, Aix-en-Provence, France

Grégory Lo Monaco

Aix Marseille Univ, LPS, Aix-en-Provence, France

Corresponding author: Jaïs Troïan

Aix Marseille Univ, LPS, 29 Av. Robert Schuman, 13100 Aix-en-Provence, France.

E-mail : jais.ADAM@univ-amu.fr 
The effect of Social Dominance on prejudice towards North-African minorities:

Evidence for the role of Social Representation of Secularism as a Legitimizing Myth.

\begin{abstract}
Secularism in France is both a state principle and a cultural construct, that enforces a State neutrality towards religion. Recent studies have demonstrated the emergence of a lay conception called 'New Secularism' (NS) that is used to legitimize expression of prejudice towards North African minorities. However, none have been able to yet demonstrate links between NS and Social Dominance Orientation (SDO), which would further corroborate those beliefs' role as prejudice justification. Using Social Representations Theory, we created a Secularism questionnaire and used it in a cross sectional survey $(N=261)$ that also included SDO and Generalized Prejudice measures. In order to test social representation of Secularism's legitimizing function, we derived the hypothesis that NS will mediate the link between SDO and expressed Prejudice from a Social Dominance perspective. Results support our predictions and are discussed in light of intergroup status quo legitimization processes and their links with social representations.
\end{abstract}

Keywords: Prejudice, Social Dominance, Social Representations, Legitimizing Myth, Secularism. 


\section{Introduction}

Secularism in France (known as 'laïcité') refers to a state principle first established with a 1905 law 'On the separation between State and Cults'. According to secularism, the French State and its servants must remain neutral towards religion (i.e., not to display visible religious signs) in order to allow for individual freedom of religion. This principle may be thought as a form of State 'secularity' (for a more accurate depiction, see Akan, 2009).

However, it must be noted that this definition is a legal one, but how can we then explain rising ethnic tensions and prejudice toward north African minorities that seem to be more and more justified by appealing to secularism? How is secularism reconstructed by the French and to what purpose? Could it deserve ideological goals, such as status quo maintenance? These are some of the issues this paper will try to answer.

\section{Emergence of 'New Secularism'}

Indeed, as noted by historians throughout the past decades (e.g., Baubérot, 2010, 2014), this traditional understanding of secularism has been gradually replaced in everyday life. Thus, this 'New Secularism' (NS, also referred to as 'counterfeited secularism') has emerged among the public, media and political discourse: now, individuals ought to be laic and religious signs shall not be seen in the public sphere. These two conceptions of secularism have been recently confirmed by Roebroeck and Guimond (2017). Departing from a 'positive' logic of liberty (Berlin, 1958), NS's fundamental logic has become one of restriction and social control (Vauchez \& Valentin, 2014) according to which one's religion should remain private. Thus, the principle of neutrality legally attributed to the French State has been imputed to religions. This new conception of secularism was the basis for the 2004 act forbidding visible religious signs among pupils in French public schools. Though every religion falls under the scope of this law, it was implemented after more than a decade of heated debates surrounding the 
wearing of Muslim hijab by underage pupils. In fact, as Nugier, Roebroeck et al. (2016) report, 'one argument to justify this 2004 law was that it was needed to fight against Islamic fundamentalist movements'. This has led researchers (e.g., Kamiejski, Guimond, De Oliveira, Er-Rafiy, \& Brauer, 2012) to consider the possible function of NS as a socially acceptable justification for expressing intergroup prejudice (Crandall \& Eschleman, 2003; Crandall, Eshleman, \& O’Brien, 2002), namely anti-Muslim prejudice.

\section{New Secularism and expression of prejudice}

For their part, Kamiejski et al. (2012) created a scale designed to assess the adherence of French students to Republican Ideology. It refers to the 'French Republican model of integration and organization of community life [...] model which aims at ensuring freedom, equality and brotherhood' (Kamiejski et al., 2012). Among the scale's two dimensions, a factor corresponding to NS (i.e., 'religious practice should remain as private as possible') was found. Subsequent correlational analyses revealed the NS factor to be positively linked with expression of prejudice towards people from North African descent. What is surprising here is that expressed prejudice has little to do with belonging to a religious group (Muslim) but to an ethnic one. Further studies confirmed positive correlations between NS and expressed prejudice towards North Africans (Guimond, de la Sablonnière, \& Nugier, 2014), but also towards immigrants in general (Roebroeck \& Guimond, 2015) among both students and the general population. Experimental corroboration of this phenomenon through manipulation of adherence to NS was conducted by Nugier, Oppin et al. (2016), whose results indicate that transgression of NS principles, such as wearing a visible religious sign in public, was more sanctioned when transgressors were Muslim than when they were Christian. Furthermore, individuals in the Muslim-target condition scored significantly higher on the NS subscale of the Republican Ideology Scale, indicating the justification potential of this construct. 


\section{Limitations of the republican ideology approach}

Though very interesting in highlighting the effects of NS on expressed prejudice, we wanted to complement the above-mentioned approach on several important features. The first one has to do with methodological considerations regarding the Republican Ideology Scale (RIS). Indeed, three major concerns emerge regarding this scale's construction, validation and psychometric properties. When taking a closer look at how RIS was created, one cannot help noticing that items used to assess this construct were selected by researchers on the basis of a press review and legal definitions. This might explain the sometimes poor reliability of the NS subscale ( $\alpha=.25$, Kamiejski et al., 2012, study 2$)$, because those contents might not reflect the way Secularism is perceived by lay people. Also, RIS is a measure of Republican Ideology, which mixes a dimension regarding beliefs about French citizenship (called 'colorblind equality') with another one regarding secularism, but only in its 'new' version. Notwithstanding the different nature of these two components, individuals may also hold different beliefs regarding each of these components and may not fall in a simple dichotomy between 'citizenship equalitarians' and 'new laics'.

These methodological concerns point at more theoretical issues that need to be addressed. We agree with Nugier, Oppin et al. (2016), from a justification-suppression of prejudice perspective (Crandall \& Eshleman, 2003; Crandall et al., 2002) and with their observation that NS helps to justify expression of prejudice. Furthermore, Imhoff and Recker (2012, study 2) observed that Secular Critique of Islam was correlated to prejudice toward Islam only for participants high in Social Dominance Orientation (SDO; Sidanius \& Pratto, 2001). If so, then a moderate to strong relation between NS and SDO is to be expected. This is because a higher endorsement of general status quo legitimizing myths should also be linked with endorsement of more culturally situated explanations for justifying derogation of outgroups (as would be the case for NS). In fact, from a Social Dominance perspective, beliefs 
of the NS kind can be considered as legitimizing myths that mediate the relationship between SDO (which is a general tendency to support the current status quo by adhering to legitimizing myths) and expressed prejudice (or support to anti-egalitarian policies; see Sidanius \& Pratto, 1999; Hodson, Rush, \& MacInnis, 2010).

However, from Kamiejski et al.'s (2012) study and on, no one has yet been able to consistently demonstrate such correlations by using NS subscale of the RIS. We argue that these negative results might be attributed to measurement problems. In light of these limitations, we offer to further assess these authors' hypothesis regarding the status of NS as a collective belief which has legitimizing properties, by drawing upon their work using more ecological material for measuring NS. This is why we turned to Social Representations Theory and methods.

\section{Social representations approach}

The concept of social representation (SR) was initially proposed by Moscovici (1961, 2008). SRs can be defined as structured systems of ideas, opinions, attitudes, and beliefs shared by a social group about a same social object (Keczer, File, Orosz, \& Zimbardo, 2016; Rateau, Moliner, Guimelli, \& Abric, 2011; Sammut, Andreouli, Gaskell, \& Valsiner, 2015). SRs constitute "what people think of knowing and are persuaded to know about objects, about situations, about given groups' (Abric, 1996, p. 11). Especially, it focuses on the construction of a common vision of an object or a social issue through interpersonal interactions within a social group (Moscovici, 1988, Breakwell, 1993; Brunel, et al., 2017; Moloney, Hayman, Gamble, Smith, \& Hall, 2017; Moloney \& Walker, 2002; Wagner, 1995, 1998).

The contributions in the field of SRs were developed through three main lines of research, each one aiming to develop different ways for studying SRs (Rateau et al., 2011). Originally, the sociogenetic approach (e.g., Moscovici, 2008) studies the impact of social relationships on the elaboration of SRs using monographic and qualitative methods (e.g., 
Kronberger and Wagner, 2000; Markova, 1997; Wagner, 1994; Wagner et al., 1999). Then, the structural approach (Abric, 2001; Lo Monaco, Piermattéo, Rateau, \& Tavani, 2016; Moliner \& Abric, 2015) analyzes the representational dynamics and the structural characteristics of the field of cognitions defining social representations, more specifically linked to social conduct through among other things experimental methodologies (see Lo Monaco, Piermattéo et al., 2016; see Lo Monaco, Girandola, \& Guimelli, 2016). Finally, the sociodynamic approach (Clémence, 2001; Lorenzi-Cioldi \& Clémence, 2001; 2010; Spini, 2002) investigates the shared principles which organize the interindividual differences. Moreover, this approach explores the regulatory role of SRs in connection with symbolic relationships (e.g., socioeconomic and/or cultural levels).

Moreover, the represented object is, inter alia, the object of frequent conversations and debates among social groups in which it carries different meanings and bear important identity stakes (see Breakwell, 1993; Moliner, 1993; Moscovici, 2008). This is the case for secularism in France. The interesting fact about SRs is that they provide us with a robust theoretical and methodological framework (Lo Monaco, Piermattéo et al., 2016) within which one can study content, structure (e.g., Keczer et al., 2016) and functional relationships of what could otherwise be loosely characterized as 'lay beliefs' or 'worldviews'.

In the case of secularism, we thought that investigating shared beliefs about secularism among the French with the help of mainly used methods from the field of SRs (Lo Monaco, Piermattéo et al., 2016) might provide us with interesting insights. In fact, though secularism is currently the focus of social psychological investigation in France (e.g., Roebroeck \& Guimond, 2016), very little is known about the meaning individuals spontaneously attach to it. As a reminder, Jost and Ignatow (2001) pointed out the system justification function of SRs. This reinforces the plausibility of a link between SDO, Prejudice and post hoc justification by individuals' adherence to NS (i.e., theoretical insight). A second advantage of this inductive 
approach is to obtain more ecological material, drawing upon subjects' own cognitive categories (Bruner, 1990), which constitutes a methodological gain.

A cross sectional study was designed, which included a Secularism questionnaire created with the help of SR methodology and two other constructs of interest: Social Dominance Orientation and Generalized Prejudice. This was done to carry on the work initiated by Kamiejski et al. (2012). We aimed at putting their hypothesis regarding NS as a prejudicejustification to further tests. Though this study's design is cross-sectional and does not allow for making statements about causality, we wanted to put a mediation model to the test, according to theoretical considerations. Recent research on SDO as a cause of prejudice, using longitudinal protocols (Kteily, Sidanius, \& Levin, 2011), constrained us in considering this factor as our independent variable. Indeed, it seems that SDO, though context sensitive (Guimond, Dambrun, Michinov, \& Duarte, 2003), is a rather stable construct (i.e., due to the stability of social structure) that demonstrates sufficient consistence across situations (Levin, 1996; Pratto, Sidanius, \& Levin, 2006). Then, still in line with the Social Dominance approach, NS had to constitute a mediating variable of the link between SDO and Generalized Prejudice. Thus, we expected that:

H1: Our Secularism questionnaire will? tap into at least two different dimensions, namely NS and a traditional conception of Secularism.

H2: The dimension corresponding to NS will? positively correlate with SDO.

H3: The dimension corresponding to NS will? positively correlate with Generalized Prejudice. H4: As predicted by Social Dominance theory, a positive correlation between SDO and Generalized Prejudice will? be found.

H5: The link between SDO and Generalized Prejudice will? be mediated by NS. 


\section{Method}

\section{Pre-test}

This pre-test was conducted to gather lexical content about secularism among a small sample of the French population. Then, gathered material was used to create a questionnaire for studying the dimensions of the SR of secularism.

\section{Participants}

Our pre-test sample consisted of 70 French people $(38.5 \%$ male; Mage $=31.8, S D=$ $12.5) ; 38.6 \%$ were students (college or high school), $48.6 \%$ were working and $11.4 \%$ had different background (unemployed, housewife...). Only one (1.4\%) was retired.

\section{Material and procedure}

To construct the secularism questionnaire, an online questionnaire was distributed among social networks groups. In order for the targeted groups to be as neutral as possible, we avoided contacting stereotypical gendered activity groups (e.g., soccer fan groups) and used exchange/sales/classified advertisements groups. Due to the qualitative nature of our data, which takes time to analyze, we had to restrict the number of participants. This survey was anonymous, confidential and all participants gave their written informed consent.

We used a verbal association task (e.g., Bonnec, Roussiau, \& Vergès, 2002; Jung \& Pawlowski, 2014, 2015; Pozzi, Fattori, Bocchiaro, \& Alfieri, 2014). Rooted in the structural approach of SRs, it is a widely used method allowing to gather the contents associated with a given object of SR (Lo Monaco, Piermattéo et al., 2016). Operationally, verbal associations consist in asking participants to associate a variable number of words or phrases (generally three to five; see Lo Monaco, Piermattéo et al., 2016; Piermattéo, Lo Monaco, \& Girandola, 2016) with the object of representation under study. Here, we asked participants to associate the five words or phrases that came to their mind when we say the word 'secularism' (i.e., 'laïcité' in French). Participants also had to rank the words or expressions they wrote from $1=$ 
'most important' to 5 = 'least important' (Bonnec et al. 2002; Dany, Urdapilleta, \& Lo Monaco, 2015; Lo Monaco, Piermattéo et al., 2016). Participants had then to rate the valence of the words (see Piermattéo et al., 2014) on a 7-point Likert scale ranging from -3 ('very negative') to +3 ('very positive'). If these last two measures are often part of the verbal evocation task (see Lo Monaco, Piermattéo et al., 2016), the information they provide was useless to the aims of our main study, and will therefore not be presented here. Additionally, they had to write, for each word, a sentence expressing the meaning that they wished to assign to these words or sentences in relation to secularism. Thanks to this method called "semantic contextualization" (Piermattéo, Tavani, \& Lo Monaco, 2018; see Lo Monaco, Piermattéo et al., 2016; Piermattéo, Lo Monaco, Moreau, Girandola, \& Tavani, 2014), we were able to perform a thematic content analysis (Guest, MacQueen, \& Namey, 2012), that is, a categorization of words and sentences to constitute a limited number of categories. Indeed, semantic contextualization allows for improving not only the level of agreement between researchers performing the categorization and the confidence in these categories, but also their homogeneity (Piermattéo et al., 2018).

\section{Results}

Sixteen investigators performed thematic content analysis on words from the present survey during two workshops. This analysis aimed at grouping the collected words, thanks to the semantic contextualization technique, into a small number of categories or themes. It allowed to identify seven categories summarizing all content from the verbal association task. However, being general and abstract, we could not construct items directly from these categories. Rather, we formulated them with the help of contextualisation sentences from each category in order to respect the meaning given by the participants to their own associations. Note that, when several meanings were attributed to a same category, several items corresponding to each meaning were constructed. Table 1 presents these categories, their frequency of evocation (i.e., the total number of words and expressions belonging to the 
category relative to the total number of words and expressions produced by our 70 participants through the verbal association task) and the 11 items constructed.

Table 1.

Thematic Content Analysis performed on items from the evocations task and the corresponding items constructed $(N=70)$.

\begin{tabular}{|c|c|c|}
\hline Category & $\begin{array}{l}\text { Frequency of } \\
\text { evocation }(\%)\end{array}$ & Corresponding item \\
\hline Respect & 37.7 & Secularism means respect for other people's faith \\
\hline State & 18.6 & $\begin{array}{l}\text { Secularism protects the French Republic } \\
\text { Secularism protects public places from religion }\end{array}$ \\
\hline $\begin{array}{l}\text { Individual } \\
\text { freedom }\end{array}$ & 12.3 & Secularism enforces respect for everybody \\
\hline Religion & 10 & Secularism guarantees equality between religions \\
\hline Tension & 9.7 & $\begin{array}{l}\text { Some religions go against secularism } \\
\text { Secularism worsens religious conflicts }\end{array}$ \\
\hline School & 6.6 & $\begin{array}{l}\text { School is the place where secularism is taught and } \\
\text { where religious signs shall not be seen }\end{array}$ \\
\hline $\begin{array}{l}\text { Religious } \\
\text { diversity }\end{array}$ & 5.1 & Cultural differences are deleterious to secularism \\
\hline
\end{tabular}

\section{Main study}

\section{Participants}

Our sample consists of 261 French people $(21.1 \%$ male; Mage $=32.11, S D=11.45)$; $28 \%$ were students (i.e., college or high school), $53.6 \%$ were working, $1.9 \%$ of them were retired and $16.5 \%$ had other background. Within this sample, $48.7 \%$ declared being religious. This sample size was over $N=250$ allowing us to provide stable estimates of the links between the constructs under investigation (see Schönbrodt \& Perugini, 2013). 
In order to determine the power achieved by this study, we computed post hoc power analyses with the help of GPower ${ }^{\circledR}$. The parameters were set as follows: correlation size $r=$ .30 for $\mathrm{H}_{1}$ (our conservative threshold); correlation size $r=.10$ for $\mathrm{H}_{0}$ (corresponds to a small correlation, thus ambient noise); two-tailed test; $\alpha=.05$; for a total $N=261$. It yielded an achieved power of $\beta=.92$.

\section{Procedure}

An online survey was then created and distributed among social networks groups using the same procedure than for constructing the secularism questionnaire. The survey included first the secularism questionnaire (11 items, 7-point Likert scale), then a French version of the SDO scale (10 items, 7-point Likert scale; Pratto, Sidanus, Stallworth, \& Bertram, 1994; see Duarte, Dambrun, \& Guimond, 2004 for the French validation), and of the Generalized Prejudice Scale (GP, 15 items, 7-point Likert scale, Dambrun \& Guimond, 2001). Finally, participants had to fill in demographics (i.e., age, gender, occupation, religion, education). This survey was anonymous, confidential and all participants gave their written informed consent. Results

Due to the cross-sectional nature of this study, some precautions were implemented. In order to render correlations more interpretable and maximize the likelihood of detecting 'theoretically' significant effects, we decided to set a minimum (conservative) correlation threshold of $r=.30$, thus maximizing the odds of excluding correlational ambient noise (Lykken, 1968; Meehl, 1990) and spurious correlations due to Common Methods Variance (Reio, 2010). All correlation analyses were bivariate Pearson correlations.

Exploratory factor analysis was conducted using Maximum Likelihood factor analysis with a Promax rotation on its 11 items (see Costello \& Osborn, 2005). Two items (i.e., 'The Republic must enforce freedom of religion through secularism' and 'The State must follow a neutrality principle') saturated both on a first factor and a third one which eigenvalue was too 
weak to be retained $(<1)$. Thus, the most parsimonious model that was yielded was a 2dimensional, 9-items solution which was therefore chosen. It explained $47.2 \%$ of total variance $\left(\mathrm{KMO}=.82\right.$; Bartlett's test of sphericity: $\chi^{2}(36)=819.3 ; p<.001$; see Table 2$)$. As expected and in line with the results found by Roebroeck and Guimond (2017) on the basis of the structure of attitudes, two dimensions were found.

Based on item content and correlation patterns with other constructs (see table 3), we interpreted Factor 1 as closer to Traditional Secularism (6 items; e.g. 'Secularism guarantees equality between religions', 'Secularism means respect for other people's faith', negatively correlated with SDO), Factor 2 (3 items, e.g., 'Cultural differences are deleterious to secularism', positively correlated with SDO and GP) as closer to New Secularism so these were labelled accordingly. Given these results, $H 1$ cannot be rejected.

We thus proceeded to factor score computation. Also, correlation analyses between SR of Secularism's two dimensions and demographics (i.e., age, gender, education and religiousness) were performed. This was done to check for potential demographic confounds. None of the obtained significant correlations were higher than $r=.20$ and were thus treated as 'ambient noise'. Before carrying out data analysis, we computed Cronbach's alphas for SDO $(\alpha=.88)$, GP $(\alpha=.93)$, TS $(\alpha=.86)$ and NS $(\alpha=.59)$. NS' reliability seemed low, but this might be due to the number of items (only 3). Thus, we computed NS' mean inter-item reliability, which is not sensitive to the number of items, providing a more accurate estimate of this dimension's reliability. It was of $r=.32$, which was deemed acceptable (optimal inter-item correlation should be comprised between .20 to .40, see Briggs \& Cheek, 1986). 
Table 2.

Summary of Exploratory Factor Analysis Results for social representations of secularism measures using Maximum Likelihood (Promax rotation; $N=261$ ).

\begin{tabular}{|c|c|c|}
\hline Items & $\begin{array}{l}\text { Factor 1: } \\
\text { Traditional } \\
\text { Secularism }\end{array}$ & $\begin{array}{l}\text { Factor 2: } \\
\text { New } \\
\text { Secularism }\end{array}$ \\
\hline Secularism enforces respect for everybody & .800 & -.162 \\
\hline Secularism guarantees equality between religions & .759 & -.114 \\
\hline Secularism protects public places from religion & .706 & .133 \\
\hline Secularism protects the French Republic & .672 & .005 \\
\hline $\begin{array}{l}\text { School is the place where secularism is taught and where } \\
\text { religious signs shall not be seen }\end{array}$ & .620 & .267 \\
\hline Secularism means respect for other people's faith. & .531 & -.170 \\
\hline Cultural differences are deleterious to secularism & .075 & .749 \\
\hline Some religions go against secularism & .261 & .595 \\
\hline Secularism worsens religious conflicts & -.299 & .425 \\
\hline Eigenvalues & 3.00 & 1.25 \\
\hline$\%$ of variance & 33.28 & 13.92 \\
\hline
\end{tabular}

Correlation analyses can be seen in Table 3. As expected, associations between NS and SDO were found. Indeed, we can see that NS positively correlates with SDO $(r=.35 ; p<.001)$ yielding a Cohen's $d=.75$. Thus, $H 2$ cannot be rejected. NS also positively correlates with GP $(r=.55 ; p<.001 ; d=1.32), H 3$ cannot be rejected. Finally, the well documented correlation between SDO and GP was found $(r=.35 ; p<.001 ; d=.75)$ which lead us not to reject $H 4$. 
Also, an unexpected, negative correlation was found between TS and SDO $(r=-.29 ; p<.001$; $d=-.61)$.

Table 3.

Bivariate correlations between Social Representations of Secularism, Social Dominance Orientation and Generalized Prejudice $(N=261)$.

\begin{tabular}{lllll}
\hline & 1 & 2 & 3 & 4 \\
\hline $\mathrm{NS}$ & - & & & \\
$\mathrm{TS}$ & $.15^{*}$ & - & & \\
$\mathrm{SDO}$ & $.35^{* * *}$ & $-.29 * * *$ & - & \\
$\mathrm{GP}$ & $.55^{* * *}$ & -.05 & $.35^{* * *}$ & - \\
\hline
\end{tabular}

Note. $* * p<.01, * * * p<.001$.

NS $=$ New Secularism; TS $=$ Traditional Secularism; SDO = Social Dominance Orientation; $\mathrm{GP}=$ Generalized Prejudice.

Since all correlations were obtained between our three variables of interest, we proceeded to the test of our mediation hypothesis (H5). A mediation analysis was thus carried out using bootstrap methods with the help of PROCESS (Hayes, 2013). Number of bootstrap samples was set at 5000 and all variables were standardized to get coefficients strictly equivalent to betas. NS was used as our mediating variable. As shown in Figure 1, there is indeed a partial mediation of SDO's effect on GP by NS. In other words, higher SDO levels predicts higher adherence to NS which in turn legitimize higher expression of prejudice. The predictors explained $31 \%$ of GP' variance, $F(2,258)=57.67, p<.001$. SDO's indirect effect through NS upon GP was $\beta=.17 ; p<.001, Z=4.92 ; p<.001$. NS' mediation effect size was $R^{2}=.09,95 \%$ CI $[.04 ; .16]$. 


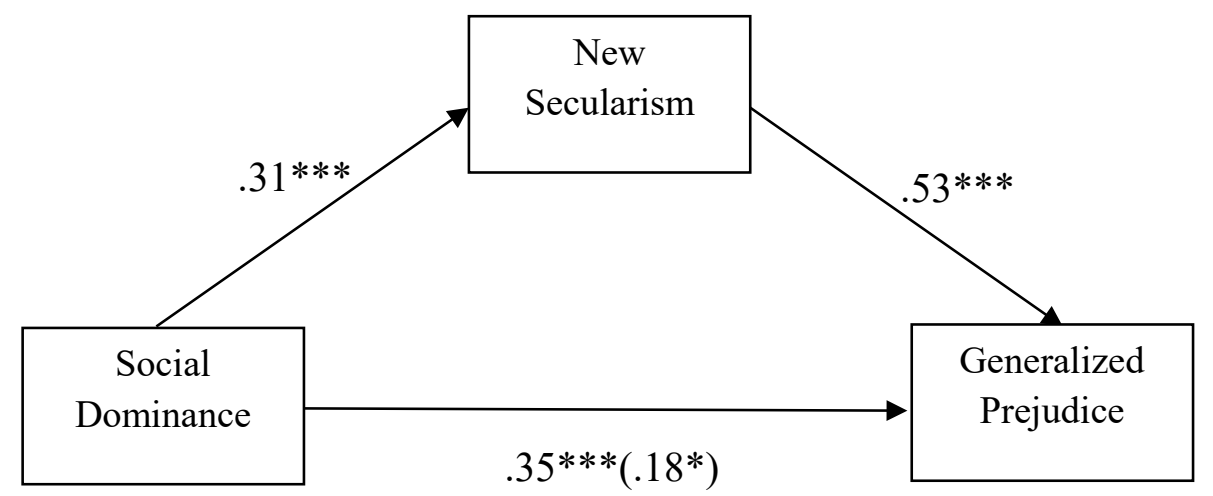

Figure 1. Partial mediation model of Social Dominance Orientation's effects on Generalized Prejudice by New Secularism. ${ }^{*} p<.05, * * * p<.001$, numbers represent beta coefficients for each path.

\section{Discussion}

The Secularism scale demonstrated adequate psychometric properties, with regards to factor structure, total explained variance and theoretical relevance. We were able to observe significant, positive correlations between Social Dominance Orientation (SDO), Generalized Prejudice (GP) and a specific dimension pertaining to SR of secularism, namely New Secularism (NS). Finally, a mediation analysis lent support to the hypothesis of NS's function for prejudice expression justification. Since these results are in line with expectations drawn from previous studies, theoretical and methodological consequences will now be reviewed.

This study allowed us to explore the SR of Secularism among the French and further corroborate its prejudice legitimizing function. We have seen that this SR included two dimensions. A first dimension, Traditional Secularism, does not seem to be meaningfully correlated with GP, indicating that it might only reflect descriptive aspects of Secularism that do not tap into any normative processes linked to prejudice-justification outcomes, though it is negatively correlated with SDO. This is a curious finding given that most previous studies have found Traditional Secularism to be negatively associated with GP measures (see Roebroeck, \& 
Guimond, 2016). This might be explained by differences in our samples (i.e., general population) or our measure of TS. This contradictory result calls for subsequent research in that direction.

The second dimension, NS, bears resemblance to the 'Laïcité factor as measured by the Republican Ideology Scale (Nugier, Oppin et al., 2016) and replicates findings from Roebroeck \& Guimond (2016) whom recently obtained positive correlations between SDO and NS. In fact, because those correlations were not observed in samples from Kamiejski et al. (2012), we can hypothesize that time could be at play in the formation of NS as a legitimizing myth. Indeed, our study was conducted in 2016, in a post terror attack context and those of Roebroeck and Guimond (2016) were carried out in a post-2008 crisis situation. If Secularism can be used as malleable ideology for coping with both symbolic and realistic threats as recent studies suggest (Roebroeck \& Guimond, 2017, in press), then time (through prevalence of societal threat) might explain these differentiated results regarding SDO's link with NS.

Our inductive approach based on participant's situated knowledge, SR of Secularism allowed us here to uncover a relevant dimension, NS, which appears to act as a socially acceptable way to justify prejudice (especially directed at North African minorities). This is because it allows one to invoke cultural differences and general religious tensions in order to make an implicit statement about one particular religion (Islam) linked to perceptions of a specific minority (North African minorities) in a subtle way. This legitimizing dimension is in line with research on modern racism (McConahay, 1986) that emphasizes a clear-cut distinction between so called 'blatant' and 'subtle' prejudice. Mediation analysis did lend support to this hypothesis. These results not only corroborate Nugier, Guimond and Kamiejski's hypothesis regarding the justification function of Secularism, they also give a finer depiction of socially shared beliefs of it and show us that an important dimension bears normative and ideological implications. Normative because NS allows socially acceptable 
prejudice justification, ideological because those expressed prejudice and their justification seem to be rooted in social dominance, thus motivated by a need to preserve and maintain existing societal structures and group asymmetries (Sibley \& Duckitt, 2010). More generally speaking, our results suggest a functional correspondence between internalized structural factors (social hierarchy) that trigger adherence to culturally acceptable narratives (legitimizing myths) that serve to justify intergroup prejudice on an interpersonal level (Doise, 1980, 1986). Thus, the study of SR (such as Secularism in France) brings an extended socio-cognitive frame allowing for the exploration of socially regulated cognitive processes at stake in the study of intergroup relations. Furthermore, the relatively small size of NS's correlations with demographics point at the relevance of approaching these issues with a strong emphasis upon psychosocial factors, in line with social psychology's historical interest in distinguishing between 'objective' group memberships and individuals' reference groups (Merton \& Kitt, 1950).

Though theoretical considerations were a prime motive for conducting this study, another objective was also attained. We demonstrated the feasibility and relevance of using a more ecological approach for studying both content and functional relationships between universal and situated socio-cognitive constructs. This framework allowed us not only to unveil hidden content that was not a priori deducible by researchers and to operationalize its quantitative measurement, but also to assess 'hot' cognition in action (Abelson, 1963) and the way it is mobilized in order to deserve inter-group and ideological motives. This method can thus be used across contexts and populations, with other 'local' legitimizing myths. Taking this kind of cognitive content into account matters, because it can then be used in other protocols assessing general social-cognitive processes of interest to researchers. It is part of a need to combine both constructionist and experimental paradigms in social psychology (Jost \& 
Ignatow, 2001; Jost \& Kruglanski, 2002) in order to gain a better understanding of phenomena under investigation, and thus, increase our theories' explanatory power.

This study being exploratory, some inherent limitations and biases need to be pointed out. One is, of course, the cross-sectional nature of the design. The mediation mechanisms uncovered through bootstrap analyses need further validation and experimental corroboration. Also, concerns can be raised regarding the hypothesized conceptual relations between our questionnaire and the Republican Ideology Scale. Indeed, to address such concerns, further research is needed in order to a) assess the links between NS's subscale and Kamiejski et al.'s RIS for theoretical matters, b) further explore and validate our Secularism questionnaire's structure on a larger sample of the French Population. In fact, alternative theoretical considerations could account for our data. First, our NS measure might tap into a form of implicit negative orientation towards Islam which, when accounted for, could make our patterns of correlations vanish. Moreover, it is possible that NS reflects a specific instantiation of cultural prejudice in itself, which would explain its strong links with GP. Experimental protocols should thus be carried out in order to (dis)confirm NS role as prejudice justification, and as discriminatory behavior justification, not only prejudice expression. Finally, our sample was $80 \%$ female, as it is often the case when carrying out online surveys. Though no relevant influence of gender was observed on NS, our design is not sufficiently equipped to firmly rule it out. Of course, further research need to include measures such as social identification (Tajfel \& Turner, 1986) or group fusion (Atran, Sheikh, \& Gomez, 2014) to empirically link our findings with social identity stakes and to obtain a better picture of the group identities at play within this framework and representations of Secularism's social nature. We argue that, given the weak direct effect of SDO on NS, we may well be facing a total mediation. One reason for the statistical significance of this effect should be the use of bootstrap methods, which are 
considerably more powerful (Shrout \& Bolger, 2002) and thus more able to detect small (and sometimes trivial) effects.

\section{Conclusion}

This study aimed at understanding the function of culturally situated beliefs (i.e., Secularism) and their links with psychosocial processes at work on both ideological and intergroup levels in France. Understanding these phenomena bear important stakes in the present political and societal situation (i.e., controversies surrounding the 'burkini' and the following discriminatory practices of civil servants toward minorities). Furthermore, we argue that even if secularism is specific to a French context, its role and function can be found across countries and cultures. Even if the SR used to legitimize prejudice can vary significantly between populations and social groups, the justification process is expected to be relatively stable. Thus, our method could serve the purpose of identifying specific socio-cognitive categories mobilized in prejudice justification in order to assess the extent to which content impacts processes (and the other way round). Studying 'hot' political cognitive processes (Jost, Hennes, \& Lavine 2013) involved in intergroup conflicts and prejudice justification with a mixed theoretical framework may be fruitful. Indeed, it could help us shed light on the way ideological and social factors shape the construction of other beliefs, and 'color' people's worldviews with regards to group identity motives. This framework could allow us to dive deeper in the understanding of emergent political behaviors, in a context of perceived threat favoring the revival of extreme votes, defiance against 'traditional' political parties and rising ethnic tensions across Western democracies. 


\section{References}

Abelson, R. (1963). Computer simulation of "hot" cognition. In S. Tomkins, \& D. Messick (Eds.), Computer Simulation of Personality (pp. 277-298). New York: Wiley. Abric, J.-C. (1996). De l'importance des représentations sociales dans les problèmes de l'exclusion sociale [Of the importance of social representations in the problems of social exclusion]. In J.-C. Abric (Ed.), Exclusion sociale, insertion et prevention [Social exclusion, insertion and prevention] (pp. 11-17). Ramonville St Agne: Eres.

Abric, J.-C. (2001a). A structural app 1 roach to social representations. In K. Deaux \& G. Philogène (Eds.), Representations of the Social: Bridging theoretical traditions (pp. 42-47). Oxford, UK, Malden, MA: Blackwell.

Akan, M. (2009). Laïcité and multiculturalism: The Stasi Report in context. The British journal of sociology, 60, 237-256. doi: 10.1111/j.1468-4446.2009.01229.x

Atran, S., Sheikh, H., \& Gomez, A. (2014). Devoted actors sacrifice for close comrades and sacred cause. Proceedings of the National Academy of Sciences, 111, 17702-17703.

Baubérot, J. (2010). Histoire de la laïcité en France [History of secularism in France]: «Que sais-je? ». Paris: Presses Universitaires de France.

Baubérot, J. (2014). Les laïcités dans le monde [Secularism around the world] : "Que saisje? ». Paris: Presses Universitaires de France.

Berlin, I. (1958). Four Essays on Liberty. Oxford: Oxford University Press.

Bonnec, Y., Roussiau, N., \& Vergès, P. (2002). Categorical and prototypical analysis: A study on the quality-process in hospital institutions. European Review of Applied Psychology, 52, 213-220.

Breakwell, G. M. (1993). Social representations and social identity. Papers on Social Representations, 2, 198-217. 
Briggs, S. R., \& Cheek, J. M. (1986). The role of factor analysis in the development and evaluation of personality scales. Journal of Personality, 54, 106-148. doi: 10.1111/j.1467-6494.1986.tb00391.x

Brunel, M., Launay, C., Le Floch, V., Py, J., Cascino, N., Zorapapillan, M., \& Lo Monaco, G. (2017). Is the social representation of nanotechnology anchored in that of GMOs?. Journal of Risk Research, 1-16. doi: 10.1080/13669877.2017.1304976

Bruner, J. S. (1990). Acts of meaning (Vol. 3). Cambridge, MA: Harvard University Press.

Clémence, A. (2001). Social positioning and social representations. Blackwell Publishing.

Costello, A. B., \& Osborne, J. W. (2005). Best practices in exploratory factor analysis : Four recommendations for getting the most from your analysis. Practical Assessment, Research \& Evaluation, 10, 173-178.

Crandall, C. S., \& Eshleman, A. (2003). A justification-suppression model of the expression and experience of prejudice. Psychological bulletin, 129, 414-446. doi: 10.1037/0033-2909.129.3.414

Crandall, C. S., Eshleman, A., \& O'Brien, L. (2002). Social norms and the expression and suppression of prejudice: the struggle for internalization. Journal of Personality and Social Psychology, 82, 359-378. doi: 10.1037/0022-3514.82.3.359

Dambrun, M., \& Guimond, S. (2001). The theory of relative deprivation and hostility towards North Africans. International Review of Social Psychology, 72, 23-36. doi: $10.3917 /$ cips.072.0023

Dany, L., Urdapilleta, I., \& Lo Monaco, G. (2015). Free associations and social representations: some reflections on rank-frequency and importance-frequency methods. Quality \& Quantity, 49, 489-507. doi: 10.1007/s11135-014-0005-z

Doise, W. (1980). Levels of explanation in the European Journal of Social Psychology. European Journal of Social Psychology, 10, 213-231. doi: 10.1002/ejsp.2420100302 
Doise, W. (1986). Levels of explanation in social psychology. Cambridge: Cambridge University Press.

Duarte, S., Dambrun, M., \& Guimond, S. (2004). La dominance sociale et les" mythes légitimateurs": Validation d'une version française de l'échelle d'orientation à la dominance sociale [Social dominance and legitimizing myths: Validation of a French version of the Social Dominance Orientation scale], International Review of Social Psychology, 17, 97-126.

Guest, G., MacQueen, K. M., \& Namey, E. E. (2012). Applied thematic analysis. Thousand Oaks, CA: Sage.

Guimond, S., Dambrun, M., Michinov, N., \& Duarte, S. (2003). Does social dominance Generate prejudice? Integrating individual and contextual determinants of intergroup cognitions. Journal of Personality and Social Psychology, 84, 697-721. doi: $10.1037 / 0022-3514.84 .4 .697$

Guimond, S., de la Sablonnière, R., \& Nugier, A. (2014). Living in a multicultural world: Intergroup ideologies and the societal context of intergroup relations. European Review of Social Psychology, 25, 142-188. doi: 10.1080/10463283.2014.957578

Hayes, A.F. (2013). Introduction to mediation, moderation, and conditional process analysis: A regression-based approach. New York: Guilford Press.

Hodson, G., Rush, J., \& MacInnis, C. C. (2010). A joke is just a joke (except when it isn't): Cavalier humor beliefs facilitate the expression of group dominance motives. Journal of Personality and Social Psychology, 99, 660-682. doi: 10.1037/a0019627

Hogg, M., \& Abrams, D. (1990). Social identifications: A social psychology of intergroup relations and group processes. London: Routledge.

Imhoff, R., \& Recker, J. (2012). Differentiating Islamophobia: Introducing a new scale to measure Islamoprejudice and secular Islam critique. Political Psychology, 33, 
811-824. doi: 10.1111/j.1467-9221.2012.00911.x

Jost, J.T., Hennes, E.P., \& Lavine, H. (2013). 'Hot' political cognition: Its self-, group, and system-serving purposes. In D. Carlston (Ed.), Oxford handbook of social cognition (pp. 851-875). New York: Oxford University Press.

Jost, J.T., \& Ignatow, G. (2001). What we do and don't know about the functions of social representations. In K. Deaux, \& G. Philogene (Eds.), Representations of the social: Bridging theoretical traditions (pp. 190-198). Oxford: Blackwell Publishing Ltd.

Jost, J.T., \& Kruglanski, A. W. (2002). The estrangement of social constructionism and experimental social psychology: History of the rift and prospects for reconciliation. Personality and Social Psychology Review, 6, 168-187.

doi: 10.1207/S15327957PSPR0603_1

Jung, Y., \& Pawlowski, S. D. (2014). Virtual goods, real goals: Exploring means-end goal structures of consumers in social virtual worlds. Information \& Management, 51, 520-531. doi:10.1016/j.im.2014.03.002

Jung, Y., \& Pawlowski, S. D. (2015). The meaning of virtual entrepreneurship in social virtual worlds. Telematics and Informatics, 32, 193-203.

doi:10.1016/j.tele.2014.07.002

Kamiejski, R., Guimond, S., De Oliveira, P., Er-Rafiy, A., \& Brauer, M. (2012). Le modèle républicain d'intégration : implications pour la psychologie des relations entre groupes [The republican model of integration:Implications for the psychology of intergroup relations]. L'Année Psychologique, 112, 49-83.

doi: $10.4074 / \mathrm{S} 0003503312001030$

Keczer, Z., File, B., Orosz, G., \& Zimbardo, P.G. (2016). Social Representations of Hero and Everyday Hero: A Network Study from Representative Samples. Plos One, 11. doi: 10.1371/ journal.pone.0159354. 
Kronberger, N., \& Wagner, W. (2000). Keywords in context: Statistical analysis of text features. In M. W. Bauer \& G. Gaskell (Eds.), Qualitative researching with text, image and sound. A pratical handbook (pp. 299-317). London: Sage Publications.

Kteily, N. S., Sidanius, J., \& Levin, S. (2011). Social dominance orientation: Cause or 'mere effect'? Evidence for SDO as a causal predictor of prejudice and discrimination against ethnic and racial outgroups. Journal of Experimental Social Psychology, 1, 208-214. doi: 10.1016/j.jesp.2010.09.009

Levin, S. L. (1996). A social psychological approach to understanding intergroup attitudes in the United States and Israel. Doctoral dissertation, Department of Psychology, University of California, Los Angeles.

Lo Monaco, G., Delouvée, S., \& Rateau, P. (2016). Les représentations sociales. Théories, méthodes et applications [Social representations. Theories, methods and applications]. Bruxelles: De Boeck.

Lo Monaco, G. L., Girandola, F., \& Guimelli, C. (2016). Experiments inter-connecting the structure of social representations, cognitive dissonance, commitment and persuasion: past, present and future. Papers on Social Representations, 25, 5-1.

Lo Monaco, G., Piermattéo, A., Rateau, P., \& Tavani, J. L. (2016). Methods for Studying theStructure of Social Representations: A Critical Review and Agenda for Future Research. Journal for the Theory of Social Behaviour. doi: 10.1111/jtsb.12124

Lorenzi-Cioldi, F., \& Clémence, A. (2001). Group processes and the construction of social representations. In M. A. Hogg \& R. S. Tindale (Eds.), Blackwell Handbook of Social Psychology: Group Processes (pp. 311-333). Oxford: Blackwell Publishers Ltd.

Lorenzi-Cioldi, F., \& Clémence, A. (2010). Social representations. Encyclopedia of Group Processes and Intergroup Relations, 2, 823-826.

Lykken, D. T. (1968). Statistical significance in psychological research. Psychological 
Bulletin, 70, 151-159. doi: 10.1037/h0026141

Marková, I. (1997). Language and authenticity. Journal for the Theory of Social behaviour, 27, 265-275. doi: 10.1111/1468-5914.00037

McConahay, J. B. (1986). Modern racism, ambivalence, and the modern racism scale. In. J.F. Dovidio, \& S.L. Gaertner (Eds.), Prejudice, discrimination, and racism (pp. 91-125). San Diego, CA: Academic Press.

Meehl, P. E. (1990). Why summaries of research on psychological theories are often uninterpretable. Psychological Reports, 66, 195-244. doi: 10.2466/pr0.1990.66.1.195

Merton, R. K., \& Kitt, A. S. (1950). Contributions to the theory of reference group behavior. In R. K. Merton \& P. F. Lazarsfeld (Eds.), Continuities in social research: Studies in the scope and method of 'The American Soldier'(pp. 40-105). Glencoe, IL: Free Press.

Moliner, P. (1993). Cinq questions à propos des représentations sociales [Five questions about social representations]. Cahiers Internationaux de Psychologie Sociale, 20, 5 14.

Moliner, P., \& Abric, J. C. (2015). Central core theory. In G. Sammut, E. Andreouli, G. Gaskell, \& J. Valsiner (Eds.), The Cambridge Handbook of Social Representations (pp. 83-95). Cambridge: Cambridge University Press

Moloney, G., Hayman, J., Gamble, M., Smith, G., \& Hall, R. (2017). Translation strategies, contradiction, and the theory of social representations: Why discussing needles may improve blood donor retention. British Journal of Social Psychology, 56, 393-415. doi: $10.1111 /$ bjso.12187

Moloney, G., \& Walker, I. (2002). Talking about transplants: Social representations and the dialectical, dilemmatic nature of organ donation and transplantation. British Journal of Social Psychology, 41, 299-320. doi: 10.1348/014466602760060264

Moscovici, S. (1961). La psychanalyse, son image et son public [Psychoanalysis, its image 
and its public]. Paris: Presses Universitaires de France.

Moscovici, S. (1988). Notes towards a description of social representations. European journal of social psychology, 18, 211-250. doi: 10.1002/ejsp.2420180303

Moscovici, S. (2008). Psychoanalysis, its image and its public. Cambridge: Polity Press.

Nugier, A., Roebroeck, E., Anier, N., Kleinlogel, E., Chatard, A., Guimond, S. (2016). The Psychological Effects of Terrorism are Moderated by Cultural Worldviews. International Review of Social Psychology, 29, 77-84. doi: 10.5334/irsp.61

Nugier, A., Oppin, M., Cohu, M., Kamiejski, R., Roebroeck, E., \& Guimond, S. (2016). Secularism in France and Normative Pressure Against Muslim Minorities. International Review of Social Psychology, 29, 15-30. doi: 10.5334/irsp.11

Piermattéo, A., Lo Monaco, G., \& Girandola, F. (2016). When commitment can be overturned: Anticipating environmental program dropouts through social representations. Environment and Behavior, 48, 1270-1291. doi: $10.1177 / 0013916515597511$

Piermattéo, A., Lo Monaco, G., Moreau, L., Girandola, F., \& Tavani, J.-L. (2014). Context Variations and Pluri-methodological Issues concerning the Expression of a Social Representation: the Example of the Gypsy Community. The Spanish Journal of Psychology, 17. doi: 10.1017/sjp.2014.84

Piermattéo, A., Tavani, J.-L., \& Lo Monaco, G. (2018). Improving the study of social representations through word Associations: Validation of semantic contextualization. Field Methods.

Pozzi, M., Fattori, F., Bocchiaro, P., \& Alfieri, S. (2014). Do the right thing! A study on social representation of obedience and disobedience. New Ideas in Psychology, 35, 18-27. doi: 10.1016/j.newideapsych.2014.06.002

Pratto, F., Sidanius, J., \& Levin, S. (2006). Social dominance theory and the dynamics of 
intergroup relations: Taking stock and looking forward. European Review of Social Psychology, 17, 271-320. doi: 10.1080/10463280601055772

Pratto, F., Sidanius, J., Stallworth, L. M., \& Malle, B. F. (1994). Social dominance orientation: A personality variable predicting social and political attitudes. Journal of Personality and Social Psychology, 67, 741-763.

Rateau, P., Moliner, P., Guimelli, C., \& Abric, J. (2011). Social Representation Theory. In P. Van Lange, A. Kruglanski, \& T. Higgins (Eds.), Handbook of Theories of Social Psychology (Vol. 2, pp. 478-498). London, Thousand Oaks, CA: Sage.

Reio, T. G. (2010). The threat of common method variance bias to theory building. Human Resource Development Review, 9, 405-411. doi: 10.1177/1534484310380331

Roebroeck, E., \& Guimond, S. (2015). Schooling, citizen-making, and anti-immigrant prejudice in France. Journal of Social and Political Psychology, 3, 20-42. doi:10.5964/jspp.v3i2.391

Roebroeck, É., \& Guimond, S. (2016). Pour une psychologie sociale de la laïcité: Identification et mesure de deux conceptions distinctes de la laïcité. L'Année psychologique, 116(4), 489-518.

Roebroeck, E., \& Guimond, S. (2017). Intergroup Threat, Social Dominance and the Malleability of Ideology: The Importance of Conceptual Replication: Malleability of Ideology. European Journal of Social Psychology. doi: 10.1002/ejsp.2311

Rosenblatt, A., Greenberg, J., Solomon, S., Pyszczynski, T., \& Lyon, D. (1989). Evidence for terror management theory: I. The effects of mortality salience on reactions to those who violate or uphold cultural values. Journal of Personality and Social Psychology, 57, 681-690. doi: 10.1037/0022-3514.57.4.681

Sammut, G., Andreouli, E., Gaskell, G., \& Valsiner, J. (Eds.). (2015). The Cambridge Handbook of Social Representations. Cambridge: Cambridge University Press. 
Schönbrodt, F. D., \& Perugini, M. (2013). At what sample size do correlations stabilize? Journal of Research in Personality, 47, 609-612. doi: 10.1016/j.jrp.2013.05.009

Shrout, P. E., \& Bolger, N. (2002). Mediation in experimental and non experimental studies: New procedures and recommendations. Psychological methods, 7, 422-445. doi: $10.1037 / 1082-989 X .7 .4 .422$

Sibley, C. G., \& Duckitt, J. (2010). The ideological legitimation of the status quo: Longitudinal tests of a social dominance model. Political Psychology, 31, 109-137. doi:10.1111/j.1467-9221.2009.00747.x

Sidanius, J., \& Pratto, F. (1999). Social dominance: An intergroup theory of social hierarchy and oppression. Cambridge, England: Cambridge University Press.

Sidanius, J., \& Pratto, F. (2001). Social dominance: An intergroup theory of social hierarchy and oppression. Cambridge: Cambridge University Press.

Spini, D. (2002). Multidimensional scaling: A technique for the quantitative analysis of the common field of social representations. European Review of Applied Psychology, 52, 231-240.

Tajfel, H., \& Turner, J.C. (1986). The social identity theory of intergroup behavior. In S. Worchel \& W. Austin (Eds.), Psychology of intergroup relations (2nd ed., pp. 7-24). Chicago: Nelson-Hall.

Vauchez, S. H., \& Valentin, V. (2014). L'affaire Baby Loup ou la nouvelle laïcité [The Baby Loup case: an illustration of new secularism]. Paris: LGDJ.

Wagner, W. (1994). Fields of research and socio-genesis of social representations: a discussion of criteria and diagnostics. Social Science Information, 33, 199-228. doi: $10.1177 / 053901894033002004$ 
Wagner, W. (1995). Description, explanation and method in social representation

research. Papers on social representations, 4, 156-176.

Wagner, W. (1998). Social representations and beyond: Brute facts, symbolic coping and domesticated worlds. Culture \& Psychology, 4, 297-329.

Doi: $10.1177 / 1354067 X 9800400302$

Wagner, W., Duveen, G., Farr, R., Jovchelovitch, S., Lorenzi-Cioldi, F., Markova, I., \& Rose,

D. (1999). Theory and method of social representations. Asian Journal of Social

Psychology, 2, 95-125. doi: 10.1111/1467-839X.00028

\section{Appendix 1.}

Social Dominance Orientation Scale (Pratto, Sidanus, Stallworth, \& Bertram, 1994)

1. Some groups of people are simply inferior to other groups.

2. It's OK if some groups have more of a chance in life than others.

3 . To get ahead in life, it is sometimes necessary to step on other groups.

4. It's probably a good thing that certain groups are at the top and other groups are at the bottom.

5. Inferior groups should stay in their place.

6 . It would be good if groups could be equal.

7. Group equality should be our ideal.

8. Increased social equality.

9. We would have fewer problems if we treated people more equally.

10. No one group should dominate in society.

Generalized Prejudice Scale (Dambrun \& Guimond, 2001)

1. French people should be prioritized when it comes to employment.

2. French people should be prioritized when it comes to welfare increases.

3. French people should be prioritized when it comes to housing.

4. If there is a lot of unemployment in France, it is because foreigners are taking the jobs of French people.

5. The diversity brought by foreigners enriches the country.

6. We should not be granting French citizenship so easily.

7. Foreigners living in France should be granted the right to vote.

8. It is absurd to blame Algerians and Moroccans for France's economic problems.

9. I consider society to be unfair to Arabs.

10. The wearing of the hijab should be allowed at school.

11. We should be more restrictive towards the coming of foreign families in France.

12. Immigrants should be given more rights.

13. It is legitimate that legal immigrants should be sent back to their country of origin.

14. One can easily understand the anger of French Maghrebi.

15. I would not be worried if most of my college friends were from Arab descent. 